\title{
Characterization of Conjugative R Plasmids Belonging to the New Incompatibility Group IncU
}

\author{
By HELMUT TSCHÄPE, * ERHARD TIETZE AND \\ CHRISTIANE KOCH \\ Institut für Experimentelle Epidemiologie, Burgstrasse 37, DDR-3700 Wernigerode, \\ German Democratic Republic
}

(Received 24 October 1980; revised 12 March 1981)

Five conjugative plasmids governing different antibiotic resistance patterns were identified in wild strains of enteric bacteria isolated in Czechoslovakia and the G.D.R. between 1976 and 1979. They have been characterized as members of the new incompatibility group IncU (reference plasmid RA3 from Japan). The molecular sizes of the IncU plasmids ranged between 18 and 37 megadaltons; their restriction fragment patterns indicated them to be distinct types.

\section{INTRODUCTION}

A wide variety of different plasmids belonging to many incompatibility (Inc) groups contribute to the development of antibiotic-resistant organisms, and the incidence of conjugative $R$ plasmids has increased within the past few years (Richmond, 1975). By means of genetic tests (incompatibility and pili tests) and molecular characterization (size determination, hybridization and endonucleolytic cleavage) it has been shown that plasmids belonging to the same incompatibility group generally, but not always, have a high degree of DNA relatedness revealed by DNA reassociation and/or restriction enzyme analysis (Grindley et al., 1973; Roussel \& Chabbert, 1978; Chabbert et al., 1979; Willshaw et al., 1980; Tschäpe \& Tietze, 1980; for review, see Datta, 1979). Therefore a phylogenetic relatedness of incompatible plasmids, in spite of their different geographical and bacterial origin, has been assumed (Datta, 1979). During the surveillance of $R$ plasmids in enteric bacteria from hospital and other environments, we found, in different bacterial species, a number of conjugative plasmids that did not belong to any of the known incompatibility groups (see Datta, 1979; Novick et al., 1976; Jacob et al., 1977) and were incompatible with one another. However, they were found to be incompatible with the R plasmid RA3, from Japan, for which the group IncU had been tentatively introduced (see Sirgel et al., 1981). These plasmids are described in this paper and characterized as members of this new group IncU.

\section{METHODS}

Strains, plasmids and phages. The Escherichia coli K12 standard strains, plasmids and phages used for the characterization of plasmids were listed by Tschäpe \& Tietze (1980). Escherichia coli K12 CV601 (thr leu thi lac rif $f^{\mathrm{R}}$ ), rifampicin-resistant derivative of W677 (V. Chaloupecky, personal communication), and Salmonella typhimurium LT2 (prototroph) were also used as recipient strains. The reference plasmids for the incompatibility tests are described in Table.1. The plasmids characterized in this paper came from several different wild strains of enteric bacteria from various clinical and geographical sources (Table 2). They were collected oetween 1976 and 1979.

Genetic characterization. Plasmids were transferred by the conjugation procedure described by Tschäpe (1973). Fi character, pilus specificity and incompatibility properties were determined as described by Tschäpe \& Tietze 
Table 1. Reference plasmids used for the incompatibility testing

\begin{tabular}{|c|c|c|c|c|}
\hline \multirow[b]{2}{*}{ Plasmid } & \multicolumn{3}{|c|}{ Relevant characters* } & \multirow[b]{2}{*}{ Reference } \\
\hline & $\begin{array}{l}\text { Inc } \\
\text { group }\end{array}$ & $\begin{array}{l}\text { Drug resistance } \\
\text { markers }\end{array}$ & $\begin{array}{l}\text { Other } \\
\text { properties }\end{array}$ & \\
\hline R16 & IncB & TcSmSuAp & $\mathrm{Fi}^{-}$ & Datta (1979) \\
\hline pIE469 & IncB & SuKm & $\mathrm{Fi}^{-}$ & Tschäpe et al. (1981) \\
\hline pIP40a & IncC & $\mathrm{KmApSu}$ & $\mathrm{Fi}^{-}$ & Chabbert et al. (1972) \\
\hline pIE468 & IncC & $\mathrm{SmTpSu}$ & $\mathrm{Fi}^{-}$ & Tschäpe et al. (1981) \\
\hline RAl & Inc $C^{+}$ & $\mathrm{TcSu}$ & $\mathrm{Fi}^{-}$ & Datta (1979) \\
\hline $\mathrm{R} 71 \mathrm{lb}$ & IncD & $\mathrm{Km}$ & $\mathrm{Fi}^{+}$ & Datta (1979) \\
\hline plA4643 & IncE & CmSmSuTc & $\mathrm{Fi}^{-}$ & Arai (pers. comm.) \\
\hline R386 & IncFI & Tc & $\mathrm{Fi}^{-} \operatorname{Dps}(\mathrm{M} 13, \mathrm{fr})$ & Dennison (1972) \\
\hline R $1-19$ & IncFII & $\mathrm{Km}$ & Fi-Dps(M13, fr) & Datta (1975) \\
\hline R 124 & IncFIV & Tc & $\mathrm{Fi}^{+} \operatorname{Dps}(\mathrm{M} 13, \mathrm{fr})$ & Datta (1975) \\
\hline pIE509 & IncFV & $\mathrm{Km}$ & $\mathrm{Fi}^{+} \mathrm{Dps}(\mathrm{fr})$ & Tschäpe (unpublished) \\
\hline R27 & IncH I & Tc & $\mathrm{Fi}^{-}$ & Datta (1975) \\
\hline R 726 & IncH 1 & $\mathrm{CmSmSu}$ & $\mathrm{Fi}^{-}$ & Datta (pers. comm.) \\
\hline R478 & IncH $2 \ddagger$ & $\mathrm{TcCmKm}$ & $\mathrm{Fi}^{-}$ & Hedges et al. (1975a) \\
\hline pIE428 & IncH2 & $\mathrm{CmSmSuGm}(\mathrm{Tm})$ & $\mathrm{Fi}^{-}$ & Tschäpe et al. (1981) \\
\hline R64-11 & IncI $\alpha$ & $\mathrm{TcSm}$ & $\mathrm{Fi}^{-}-\mathrm{Dps}(\mathrm{Ifm})$ & Hedges \& Datta (1973) \\
\hline R621a & $\operatorname{IncI} \gamma$ & Tc & $\mathrm{Fi}^{-} \mathrm{Dps}(\mathrm{Ifm})$ & Hedges \& Datta (1973) \\
\hline R391 & IncJ & $\mathrm{KmHg}$ & $\mathrm{Fi}^{-}$ & Coetzee et al. (1972) \\
\hline R387 & IncK & $\mathrm{CmSm}$ & $\mathrm{Fi}^{-}$ & Hedges \& Datta (1971) \\
\hline pIE3121 & IncK & Tc & $\mathrm{Fi}^{-}$ & Tschäpe \& Tietze (1980) \\
\hline $\mathrm{R} 446 \mathrm{~b}$ & IncM & $\mathrm{TcSm}$ & $\mathrm{Fi}^{-}$ & Datta (1975) \\
\hline pIE373 & IncM & ApKmSm & $\mathrm{Fi}^{-}$ & Tietze (1980) \\
\hline R471 & IncM $\S$ & Ap & $\mathrm{Fi}^{-}$ & Hedges et al. (1975a) \\
\hline RN3 & $\operatorname{IncN}$ & $\mathrm{TcSmSu}$ & $\mathrm{Fi}^{-} \mathrm{Dps}(\mathrm{Ike}$, PRD1 $)$ & Datta \& Hedges (1971) \\
\hline pIE492 & IncN & $\mathrm{CmSmSu}$ & $\mathrm{Fi}^{-} \mathrm{Dps}(\mathrm{Ike}, \mathrm{PRD} 1)$ & Tschäpe (unpublished) \\
\hline RP1 & IncP & $\mathrm{TcKmAp}$ & $\mathrm{Fi}^{-} \mathrm{Dps}(\mathrm{PRR}$ 1, PRD 1) & Datta et al. (1971) \\
\hline Rts 1 & IncT & $\mathrm{KmTc}$ & $\mathrm{Fi}^{-}$ & Datta $(1975)$ \\
\hline RA3 & IncU & $\mathrm{CmSmSu}$ & $\mathrm{Fi}^{-}$ & Sirgel et al. (1981) \\
\hline R783 & IncV & CmSmSuAp & $\mathrm{Fi}^{-}$ & Datta (1979) \\
\hline RSa & IncW & CmSmSuKm & $\mathrm{Fi}^{-} \mathrm{Dps}$ (PRD1) & Datta (1975) \\
\hline R388 & IncW & SuTp & $\mathrm{Fi}^{-} \mathrm{Dps}(\mathrm{PRD} 1)$ & Datta \& Hedges (1972) \\
\hline R6K & Inc $X$ & SmAp & $\mathrm{Fi}^{-}$ & Kontomichalou et al. (1970) \\
\hline $\mathrm{PlCm}$ & IncY & $\mathrm{Cm}$ & $\mathrm{Fi}^{-}$ & Hedges et al. $(1975 b)$ \\
\hline R7la & Inc9 & CmSmSuTcAp & $\mathrm{Fi}^{-}$ & Chabbert et al. (1972) \\
\hline
\end{tabular}

* The abbreviations used are those of Datta (1979). Drug resistance symbols: Ap, ampicillin; Cm, chloramphenicol; Gm(Tm), gentamicin/tobramicin; Km. kanamycin: Su. sulphonamide; Tc, tetracycline; Tp, trimethoprim. Fi, fertility inhibition; Inc, incompatibility; Dps, donor phage specificity.

+ Previously designated as IncA (see Datta, 1979).

$\ddagger$ Previously designated as IncS (see Datta, 1979).

\$ Plasmids of IncL were reclassified as IncM members (Richards \& Datta, 1979).

II RA3 is the reference plasmid of IncU (see Sirgel et al., 1981).

(1980). For incompatibility tests the reference plasmids listed in Table 1 were either transferred by conjugation from $E$. coli W677 (thi thr leu) to $E$. coli $\mathrm{K} 12 \mathrm{~J} 53$ (met pro) clones carrying the plasmids described here, or $E$. coli K $12 \mathrm{~J} 53$ strains carrying the reference plasmids were superinfected by the plasmids under investigation. Fifty colonies from each cross were replica-plated twice to select for the superinfecting plasmid and then tested for the presence of the resident plasmid. The pattern of the stability of the 'doubles' and the superinfection frequency were used to define the incompatibility properties of the plasmids.

Molecular characterization. The procedure for isolation and agarose gel electrophoresis of plasmid DNA was as described by Tschäpe \& Tietze (1980). Digestion with restriction endonuclease BamHI was carried out in TM buffer $\mathrm{pH} 7.5$ (a solution containing $100 \mathrm{~mm}$-Tris and $10 \mathrm{mM}-\mathrm{MgCl}_{2}$ ). For Pst I digestion this buffer also contained $10 \mathrm{~mm}$-2-mercaptoethanol, for EcoRI treatment both $10 \mathrm{mM}-2$-mercaptoethanol and $40 \mathrm{mM}-\mathrm{NaCl}$, and for HindIII digestion $10 \mathrm{~mm}-2$-mercaptoethanol and $70 \mathrm{~mm}-\mathrm{NaCl}$. The enzymes were gifts from Dr Hartmann (ZIMET. Jena, G.D.R.). 
Table 2. Origin and properties of the plasmids investigated

\begin{tabular}{|c|c|c|c|c|c|c|}
\hline \multirow[b]{2}{*}{ Plasmid } & \multicolumn{2}{|c|}{ Source } & \multirow[b]{2}{*}{$\begin{array}{l}\text { Resistance pattern* } \\
\quad \text { in } E \text {. coli } \mathrm{K} 12\end{array}$} & \multicolumn{3}{|c|}{ Transfer frequency $\dagger$ from: } \\
\hline & $\begin{array}{c}\text { Host and } \\
\text { clinical origin }\end{array}$ & Location & & $\begin{array}{l}\text { Original } \\
\text { host to } \\
\text { CV601 }\end{array}$ & $\begin{array}{l}\text { CV601 } \\
\text { to J53 }\end{array}$ & $\begin{array}{l}\mathrm{J} 53 \\
\text { to LT2 }\end{array}$ \\
\hline pCV9 & $\begin{array}{l}\text { Proteus morganii } \\
\text { (pyelonephritis) }\end{array}$ & $\begin{array}{l}\text { Prague, } \\
\text { C.S.S.R. }\end{array}$ & CmApKm & 0.4 & 350 & 1.0 \\
\hline pIE420 & $\begin{array}{l}\text { Escherichia coli } \\
\quad \text { (pyelonephritis) }\end{array}$ & $\begin{array}{l}\text { Osterwieck, } \\
\text { G.D.R. }\end{array}$ & TcSuSmTp & 3.0 & 450 & $3 \cdot 0$ \\
\hline pIE432 & $\begin{array}{l}\text { Escherichia coli } \\
\quad \text { (hospital sewage) }\end{array}$ & $\begin{array}{l}\text { Wernigerode§, } \\
\text { G.D.R. }\end{array}$ & TpSm & 50 & 300 & $3 \cdot 0$ \\
\hline pIE447 & $\begin{array}{r}\text { Salmonella dublin } \\
\text { (gastroenteritis) }\end{array}$ & $\begin{array}{l}\text { Rostok, } \\
\text { G.D.R. }\end{array}$ & Tc & $3 \cdot 6$ & 550 & $4 \cdot 5$ \\
\hline pIE491 & $\begin{array}{l}\text { Citrobacter freundii } \\
\text { (bacteriuria) }\end{array}$ & $\begin{array}{l}\text { Wernigerode§, } \\
\text { G.D.R. }\end{array}$ & $\mathrm{TpSmSu}$ & $0 \cdot 3$ & 350 & 1.0 \\
\hline
\end{tabular}

* For abbreviations see Table 1.

t The transfer frequency is expressed as the number of transconjugant colonies per $10^{5}$ donor organisms for an $8 \mathrm{~h}$ mating. The recipient strains $E$. coli CV601 (thr leu thi lac rif ${ }^{\mathrm{R}}$ ) (see Tschäpe et al., 1981), E. coli $\mathrm{K} 12 \mathrm{~J} 53$ (met pro) and $S$. typhimurium LT2 (prototroph) were chosen as representative examples.

‡ The plasmid pCV9 was isolated by Dr V. Chaloupecky, Prague, in 1976, and sent for incompatibility testing to the Institut für Experimentelle Epidemiologie, Wernigerode.

$\S$ From the same hospital.

\section{RESULTS AND DISCUSSION}

Four conjugative $\mathbf{R}$ plasmids were isolated from clinical strains of Proteus morganii, Escherichia coli, Citrobacter freundii, and Salmonella dublin. These strains originated from different hospitals of the G.D.R. (Wernigerode, Osterwieck and Rostock) and Czechoslovak S.S.R. (Prague) and were found in various clinical cases (Table 2). A fifth plasmid was demonstrated in a strain of $E$. coli from hospital sewage.

Each of these plasmids (pCV9, pIE420, pIE432, pIE447 and pIE491) could be transferred by conjugation to $E$. coli $\mathrm{K} 12$ substrains and from them to other enteric bacteria. Although the initial transfer frequencies of the plasmids from the wild strains to $E$. coli K12 CV601 ranged from 0.4 to 50 transconjugant colonies per $10^{5}$ donor organisms, subsequent transfer between K12 strains occurred at similar frequency ( 300 to 550 transconjugant colonies per $10^{5}$ donor organisms) for all the plasmids (Table 2). As representative examples of the observed transfer frequencies, the data for transfer from $E$. coli K12 CV601 to $E$. coli $\mathrm{K} 12 \mathrm{~J} 53$, and from $E$. coli $\mathrm{K} 12 \mathrm{~J} 53$ to $S$. typhimurium LT2 were chosen. In $E$. coli $\mathrm{Hfr}(\mathrm{H})$, these plasmids did not repress the $\mathrm{F}$-pilus production and are therefore designated $\mathrm{Fi}^{-}$.

Cultures of $E$. coli $\mathrm{K} 12 \mathrm{~J} 53$ carrying the plasmids were not lysed by donor-specific phages M13, fr, Ifm, PRR1, PRD1, PR4 and Ike in surface spot tests and did not support propagation of these phages. With one exception, $E$. coli $\mathrm{K} 12$ strains carrying the plasmids listed in Table 2 did not show immunity to superinfection by the reference plasmids, and transconjugant clones stably maintained both resident and incoming plasmids. However, incompatibility was observed with the plasmid RA3, the reference plasmid for the new group IncU (see Sirgel et al., 1981). Moreover, immunity to superinfection could be demonstrated between the plasmids pCV9, pIE420, pIE432, pIE447 and pIE491 (as far as suitable markers for selections were available).

Transconjugant clones carrying two plasmids ('doubles') lost the resident plasmid if selection for the incoming plasmid was imposed. Some representative examples of these results are given in Table 3 . The results summarized in Table 3 demonstrate that the plasmids pIE420, pIE432, pIE447, pIE491 and pCV9 belong to the new incompatibility group IncU.

The molecular sizes of the IncU plasmids ranged between 18 and 37 megadaltons as determined by agarose gel electrophoresis (Table 4). The number and sizes of the fragments 
Table 3. Determination of incompatibility by testing superinfection immunity and the stability of 'doubles' in E. coli K12 J53

\begin{tabular}{|c|c|c|c|c|c|c|c|c|c|c|c|}
\hline \multirow{2}{*}{$\begin{array}{l}\text { Super- } \\
\text { infecting } \\
\text { plasmid }\end{array}$} & \multicolumn{6}{|c|}{ Transfer frequency to $\mathrm{J} 3^{*}$ with the resident plasmid: } & \multicolumn{5}{|c|}{ Stability of 'doubles' $\dagger$ with plasmid: } \\
\hline & pIE420 & pIE432 & pIE447 & pIE491 & pCV9 & None & pIE420 & pIE432 & pIE447 & pIE491 & pCV9 \\
\hline pIE420 & NT & $3 \cdot 5$ & $3 \cdot 0$ & $3 \cdot 5$ & 0.5 & 350 & NT & NT & NT & NT & 10 \\
\hline pIE432 & NT & NT & $0 \cdot 3$ & NT & 0.3 & 280 & NT & NT & 20 & NT & 20 \\
\hline plE447 & NT & 30 & NT & $2 \cdot 5$ & 55 & 360 & NT & 6 & NT & 10 & 1 \\
\hline plE491 & NT & $4 \cdot 5$ & $5 \cdot 0$ & NT & 0.5 & 300 & NT & NT & 10 & NT & 15 \\
\hline pCV 9 & 0.5 & 1.0 & $2 \cdot 5$ & $1 \cdot 5$ & NT & 510 & 13 & 1 & 10 & 15 & NT \\
\hline RA3 & 0.8 & $3 \cdot 5$ & $3 \cdot 0$ & 10 & 8 & 350 & 10 & 6 & 10 & 10 & 10 \\
\hline R 16 & 320 & 350 & 370 & 310 & 370 & 360 & 50 & 50 & NT & 50 & 50 \\
\hline plP40a & 600 & 580 & 550 & 620 & 620 & 600 & 50 & 50 & 50 & 50 & 50 \\
\hline $\mathrm{R} 711 \mathrm{~b}$ & 350 & 320 & 380 & 310 & 300 & 330 & 50 & 50 & NT & 50 & 50 \\
\hline plA4643 & 110 & 110 & 130 & 140 & 100 & 150 & 50 & 50 & 50 & 50 & 50 \\
\hline R726 & 100 & 150 & 150 & 170 & 110 & 100 & 50 & 50 & 50 & 50 & 50 \\
\hline pIE428 & 850 & 820 & 820 & 750 & 790 & 800 & 50 & 50 & 50 & 50 & 50 \\
\hline R64 & NT & 560 & 460 & 550 & 500 & 530 & NT & 50 & 50 & 50 & 50 \\
\hline R391 & 550 & 520 & 570 & 510 & NT & 580 & 50 & 50 & 50 & 50 & NT \\
\hline R387 & 120 & 120 & 100 & 150 & 130 & 160 & 50 & 50 & 50 & 50 & 50 \\
\hline pIE 373 & 380 & 360 & 350 & 300 & 300 & 350 & 50 & 50 & 50 & 50 & 50 \\
\hline RN3 & NT & 480 & 450 & 490 & 500 & 480 & NT & 50 & 50 & 50 & 50 \\
\hline $\mathrm{RPI}$ & 300 & 280 & 310 & 270 & 300 & 320 & 50 & 50 & 50 & 50 & 50 \\
\hline Rts 1 & 150 & 120 & 120 & 100 & 140 & 120 & 50 & 50 & 50 & 50 & 50 \\
\hline R783 & 340 & 370 & 390 & 300 & 310 & 360 & 50 & 50 & 50 & 50 & 50 \\
\hline RSa & 400 & 420 & 410 & 440 & 450 & 420 & 50 & 50 & 50 & 50 & 50 \\
\hline R6K & 80 & 75 & 100 & 75 & 100 & 110 & 50 & 50 & 50 & 50 & 50 \\
\hline
\end{tabular}

NT, Not testable, because suitable markers for selection were not available.

* The transfer frequency is expressed as the number of transconjugant colonies per $10^{5}$ donor organisms for a 2 h mating.

+ Fifty transconjugants which carried the superinfecting plasmid were tested for the presence of the resident plasmid. The results show the number of clones which maintained both plasmids.

Table 4. Molecular sizes and restriction patterns of the plasmids

\begin{tabular}{|c|c|c|c|c|}
\hline \multirow[b]{2}{*}{ Plasmid } & \multirow{2}{*}{$\begin{array}{l}\text { Size } \\
(\mathrm{Md})^{*}\end{array}$} & \multicolumn{3}{|c|}{ Sizes of restriction fragments $(\mathrm{Md}) \dagger$} \\
\hline & & EcoRI & BamHI & $P_{s t \mathrm{I}}$ \\
\hline $\mathrm{pCV} 9$ & 25 & - & $(25)$ & $\begin{array}{l}(14 \cdot 1), 6 \cdot 4,1 \cdot 25,1 \cdot 20 \\
1 \cdot 07,1 \cdot 00\end{array}$ \\
\hline pIE420 & 26 & $\begin{array}{l}12 \cdot 0.5 \cdot 4 \cdot 3 \cdot 6.3 \cdot 5,2 \cdot 9 \\
1 \cdot 15\end{array}$ & $\begin{array}{l}(15 \cdot 0) .3 \cdot 4 \cdot 2 \cdot 1,2 \cdot 1 \\
1 \cdot 40\end{array}$ & $(19 \cdot 7), 4 \cdot 9 \cdot 1 \cdot 40$ \\
\hline pIE432 & 28 & $\begin{array}{l}10 \cdot 9.7 \cdot 0.4 \cdot 9 \cdot 2 \cdot 8,2 \cdot 0 . \\
1 \cdot 50.1 \cdot 20\end{array}$ & $(28)$ & $(28)$ \\
\hline pIE447 & 18 & $(18)$ & $(18)$ & - \\
\hline pIE491 & 37 & $\begin{array}{l}(15 \cdot 5) .11 \cdot 0.7 \cdot 4.1 \cdot 75 \\
1.40\end{array}$ & $\begin{array}{l}(26 \cdot 7) \cdot 4 \cdot 7 \cdot 3 \cdot 0,1 \cdot 30 \\
1 \cdot 25\end{array}$ & $\begin{array}{l}(22 \cdot 2), 6 \cdot 2,2 \cdot 4,1 \cdot 90 \\
1 \cdot 80,1 \cdot 25,1 \cdot 20\end{array}$ \\
\hline $\mathrm{RA} 3$ & 29 & $\begin{array}{l}12 \cdot 7,8 \cdot 5,3 \cdot 4 \cdot 2 \cdot 3 \cdot 1 \cdot 70 \\
1 \cdot 35\end{array}$ & $(23 \cdot 5) \cdot 5 \cdot 5$ & $(22 \cdot 7), 1 \cdot 80,1 \cdot 70,1 \cdot 60$ \\
\hline
\end{tabular}

-. No sensitive sites identified.

- Molecular size of covalently closed circular (CCC) DNA in megadaltons (Md), determined by agarose gel electrophoresis. relative to CCC DNA of reference plasmids (Meyers et al., 1976) in the range 1.8, 5.5. 7.4, $21 \cdot 5.26 \cdot 0,47 \cdot 0,60 \cdot 0 \mathrm{Md}$ (Tschäpe \& Tietze. 1980).

+ For molecular size standards, phage $\lambda$ CI857 DNA digested with EcoRI or HindIII was used, which gives

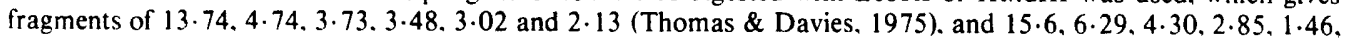
1.19 and 0.40 (Gottesman \& Adhya. 1977), respectively. Values in parentheses were estimated indirectly by calculations based on the molecular size of CCC DNA.

generated by EcoRI, BamHI and PstI differed considerably and common restriction patterns could not be observed (Table 4).

The plasmids pIE420, pIE432 and pIE491 share some drug resistance markers, but do not show any similarity in their restriction fragment pattern. The plasmids pCV9 and pIE447 
have single cleavage sites for BamHI and either one or no EcoRI cleavage site, but they differ completely in their PstI cleavage pattern. Therefore a simple derivation of the plasmids from one another, or from a common ancestor, is not supported by the evidence of their molecular sizes, restriction patterns and resistance determinants. The genetic and molecular results presented in this paper support the assumption that the five plasmids characterized here are distinct but related members of the new plasmid group IncU. However, this has to be demonstrated by analysing their polynucleotide sequence relationships.

We thank Dr Naomi Datta for the critical reading of the manuscript. We thank Dr V. Chaloupecky (Prague) for the plasmid pCV9 and Dr Naomi Datta for her generous gift of plasmid RA3. The technical assistance of Christel Strauch is acknowledged.

\section{REFERENCES}

Chabbert, Y. A., Scavizzi, M. R., Wirchitz, J. L., Gerbaud, G. R. \& Bouanchaud, D. H. (1972). Incompatibility groups and classification of $\mathrm{fi}^{-}$ resistance factors. Journal of Bacteriology 112 , 666-675.

Chabbert, Y. A., Roussel, A., Witchitz, J. L., Sanson-Le Pors, M. J. \& Courvalain, P. (1979). Restriction endonuclease generated patterns of plasmids belonging to incompatibility groups $\mathrm{I} 1, \mathrm{C}$, $\mathrm{M}$, and $\mathrm{N}$; application to plasmid taxonomy and epidemiology. In Plasmids of Medical, Environmental and Commercial Importance, pp. 183-193. Edited by K. N. Timmis \& A. Pühler. Amsterdam: Elsevier/North Holland Biomedical Press.

Coetzee, J., Datta, N. \& Hedges, R. W. (1972), $\mathrm{R}$-factors from Proteus rettgeri. Journal of General Microbiology 72, 543-552.

DATTA, N. (1975). Epidemiology and classification of plasmids. In Microbiology-1974, pp. 9-15. Edited by D. Schlessinger. Washington, D.C.: American Society for Microbiology.

DAtTA, N. (1979). Plasmid classifications: incompatibility grouping. In Plasmids of Medical, Environmental and Commercial Importance, pp. 3-12. Edited by K. N. Timmis \& A. Pühler. Amsterdam: Elsevier/North Holland Biomedical Press.

Datta, N. \& Hedges, R. W. (1971). Compatibility groups among $\mathrm{fi}^{-} \mathrm{R}$-factors. Nature, London 234 , $222-223$.

Datta, N. \& Hedges, R. W. (1972). Trimethoprim resistance conferred by $\mathrm{W}$-plasmids in Enterobacteriaceae. Journal of General Microbiology 72, 349-355.

Datta, N., Hedges, R. W., Shaw, E. J., Sykes, R. B. \& Richmond, M. H. (1971). Properties of an R-factor from Pseudomonas aeruginosa. Journal of Bacteriology 108, 1244-1249.

DENNISON, S. (1972). Naturally occurring R-factor, derepressed for pilus synthesis, belonging to the same compatibility group as the sex factor $F$ of Escherichia coli K12. Journal of Bacteriology 109, 416-422.

GottesmanN, S. \& AdhyA, S. (1977). Genetic physical and restriction map of bacteriophage lambda. In DNA Insertion Elements, Plasmids and Episomes, pp. 713-718. Edited by A. Bukhari, J. Shapiro \& S. Adhya. New York: Cold Spring Harbor Laboratory.
Grindley, N. D. F., Humphreys, G. O. \& ANDERSON, E. S. (1973). Molecular studies of R-factor compatibility groups. Journal of Bacteriology 115, 387-398.

Hedges, R. W. \& DatTA, N. (1971). Infectious drug resistance $\mathrm{f}^{-} \mathbf{R}$-factors given chloramphenicol resistance. Nature, London 234, 220-221.

Hedges, R. W. \& Datta, N. (1973). Plasmids determining I pili constitute a compatibility complex. Journal of General Microbiology 77, 19-25.

Hedges, R. W., Rodriguez-Lemoine, V. \& Datta, N. $(1975 a)$. R-factors from Serratia marcescens. Journal of General Microbiology 86, 88-92.

Hedges, R. W., Jacob, A. E., Barth, P. T. \& GrINTER, N. J. (1975b). Compatibility properties of $\mathrm{P} 1$ and $\phi \mathrm{Amp}$ prophages. Molecular and General Genetics 141, 263-267.

Jacob, A. E., Shapiro, J. A., Y amamoto, L., Smith, D. I., Cohen, S. N. \& Berg, D. (1977). Plasmids studied in Escherichia coli and other enteric bacteria. In DNA Insertion Elements, Plasmids and Episomes, pp. 607-638. Edited by A. I. Bukhari, A. Shapiro \& S. L. Adhya. New York: Cold Spring Harbor Laboratory.

Kontomichalou, P., Mitani, M. \& Clowes, R. C. (1970). Circular R-factor molecules controlling penicillinase synthesis replicating in $E$. coli under relaxed or stringent control. Journal of Bacteriology 104, 34-45.

Meyers, J. A., Sanchez, D., Elwell, L. P. \& Falkow, S. (1976). Simple agarose gel electrophoretic method for the identification and characterization of plasmid DNA. Journal of Bacteriology 127, 1529-1537.

Novick, R. P., Clowes, R. C., Cohen, S. N., Curtiss III, R., DatTA, N. \& Falkow, S. (1976). Uniform nomenclature for bacterial plasmids: a proposal. Bacteriological Reviews 40, 168-189.

RichaRDS, H. \& DATTA, N. (1979). Reclassification of incompatibility group L (IncL). Plasmid 2, 293-295.

RichMOND, M. H. (1975). R-factors in man and his environment. In Microbiology-1974, pp. 27-35. Edited by D. Schlessinger. Washington, D. C.: American Society for Microbiology.

Roussel, A. F. \& Chabbert, Y. A. (1978). Taxonomy and epidemiology of Gram-negative bacterial plasmids studied by DNA-DNA filter hybridization in formamide. Journal of General Microbiology 104, 269-276. 
Sirgel, F. A., Coetzee, J. N., Hedges, R. W. \& LeCatsas, G. (1981). Phage C-1: an IncC group plasmid-specific phage. Journal of General Microbiology 122 155-160.

Thomas, M. \& Davies, R. W. (1975). Studies on the cleavage of bacteriophage $\lambda$ DNA with EcoRI restriction endonuclease. Journal of Molecular Biology 91, 315-328.

TIETZE, E. (1980). Genetische und molekulare Untersuchungen zur Struktur von Transferplasmiden. Dissertation, Halle, G.D.R.

TSCHÄPE, H. (1973). Tet-gene pick up by an F-plasmid in Proteus mirabilis. Zeitschrift für allgemeine Mikrobiologie 13, 693-700.
TSCHÄPE, H. \& TIETZE, E. (1980). Genetic and molecular characterization of $\mathbf{R}$ plasmids incompatible with R387 (IncK). Journal of General Microbiology 118, 515-521.

Tschäpe, H., Bratoeva, M., Heier, H., Tietze, E., ZIESCHÉ, K. \& RisChe, H. (1981). Zur Verbreitung transferabler $R(T p)$ und $R(G m)$-Plasmide in Enterobacteriaceae. Zeitschrift für allgemeine Mikrobiologie 21, 621-631.

Willshaw, G. A., Barclay, E. A., Smith, H. R., MCConNell, M. M. \& Rowe, B. (1980). Molecular comparison of plasmids encoding heat-labile enterotoxin isolated from $E$. coli strains of human origin. Journal of Bacteriologv 143, 168-175. 